\title{
Analisis Perjanjian Perkawinan Dan Akibat Hukumnya Ditinjau Dari Kitab Undang Undang Hukum Perdata
}

\author{
Takwim azami ${ }^{1}$ \\ Mahasiswa program magister (S2) Kenotariatan Angkatan 1X UNISSULA \\ Semarang Email: takwimazami93@gmail.com
}

\begin{abstract}
ABSTRAK
Perkawinan merupakan suatu perjanjian yang dilakukan oleh dua orang, dalam hal ini adalah perjanjian antara seorang laki-laki dan seorang perempuan dengan tujuan material, yakni membentuk keluarga (rumah tangga) yang bahagia dan kekal yang berdasarkan Ketuhanan Yang Maha Esa, sebagai asas pertama dalam Pancasila. Dalam perkawinan yang dilakukan salah satunya akan melahirkan akibat perkawinan terhadap harta kekayaan. Semakin berkembangnya situasi dan kondisi di masyarakat banyak para calon pasangan yang akhirnya memutuskan untuk membuat Perjanjian Kawin mengingat hal ini dikarenakan baik pihak lakilaki maupun perempuan mampu menghasilkan harta kekayaan masing-masing dan masih banyak alasan lain kenapa harus membuat perjanjian kawin. Perjanjian kawin adalah perjanjian yang dilakukan oleh dua orang (calon suami istri) sebelum dilangsungkanya perkawinan. Perjanjian kawin telah diatur dalam pasal 29 Undang-Undang perkawinan No 1 Tahun 1974 namun dengan lahirnya putusan mahkamah konstitusi No. 69/PUU-XIII/2015 terjadi beberapa perubahan dalam Perjanjian Kawin yang saat ini masih menjadi Pro Kontra di dalam masyarakat. Permasalahan yang diteliti dalam penelitian ini adalah: bagaimana perjanjian perkawinan ditinjau dari kitab Undang-Undang Hukum Perdata. Metode pendekatan yang digunakan adalah pendekatan hukum normatif. Sumber bahan hukum yang digunakan adalah sumber bahan hukum primer dan sumber bahan hukum sekunder berupa buku dan perundang-undangan Teknik pengumpulan bahan hukum dilakukan dengan studi dokumenya itu membaca dan mempelajari buku-buku peraturan Perundang-Undangan. Adapun analisis bahan hukum di dalam penelitian ini, dilakukan dengan mengolah dan menganalisis secara kualitatif dan dituangkan secara deskriptif. Hasil penelitian pada simpulan pertama bahwa pengaturan perjanjian kawin di Indonesia terdapat dalam beberapa Undang-Undang diantaranya KUH Perdata, UU Perkawinan No 1 Tahun 1974, KHI dan Putusan Mahkamah Konstitusi No. 69/PUU-XIII/2016.
\end{abstract}

Kata Kunci : Perkawinan, Perjanjian Kawin, Akibat Hukum

\footnotetext{
${ }^{1}$ Mahasiswa magister S2 (progam magister kenotariatan) angkatan IX UNISSULA Semarang
} 


\section{A. Pendahuluan}

Perkawinan menurut Pasal 1 Undang-Undang nomor 1 Tahun 1974 tentang perkawinan perkawinan adalah ikatan lahir batin antara seorang pria dan seorang wanita sebagai suami istri dengan tujuan membentuk keluarga (rumah tangga) yang bahagia dan kekal berdasarkan Ketuhanan Yang Maha Esa. ${ }^{2}$ Pada dasarnya perkawinan tak lain adalah peristiwa yang mengandung hak dan kewajiban, yang setelah dilakukan oleh sepasang suami istri akan menimbulkan akibat-akibat hukum antara lain munculnya akibat terhadap diri pribadi yatu mucnulnya hak dan kewajiban suami istri, akibat terhadap harta benda suami istri dan akibat perkawinan terhadap anak sebagai keturunannya. Akibat hukum yang akan kita soroti dalam penulisan ini ialah akibat hukum terhadap harta benda yang timbul akibat adanya perkawinan, yaitu munculnya harta perkawinan.

Mengenai harta perkawinan ini diatur didalam pasal 119 sampai dengan pasal 125 Kitab Undang-Undang Hukum Perdata dan dalam Undang-Undang Nomor 1 Tahun 1974 tentang perkawinan diatur dalam pasal 35 sampai dengan pasal 37. Walaupun mengatur hal yang sama namun terdapat perbedaan dalam Kitab Undang- Undang Hukum Perdata dan Undang-Undang Nomor 1 Tahun 1974 tentang Perkawinan dalam menyikapi harta perkawinan. Kitab UndangUndang Hukum Perdata menganut asas percampuran bulat, hal ini ditunjukkan dalam pasal 119 Kitab Undang-undang Hukum Perdata dimana disebutkan dalam pasal tersebut bahwa mulai saat perkawinan. Dalam Undang-undang No. 1 tahun 1974 tentang Perkawinan diatur tentang perjanjian kawin pada Pasal 29.

1. Pada waktu atau sebelum perkawinan dilangsungkan, kedua pihak atas persetujuan bersama dapat mengadakan perjanjian tertulis yang disahkan oleh Pegawai pencatat perkawinan, setelah mana isinya berlaku juga terhadap pihak ketiga sepanjang pihak ketiga tersangkut.

2. Perjanjian tersebut tidak dapat disahkan bilamana melanggar batasbatas hukum, agama dan kesusilaan.

3. Perjanjian tersebut mulai berlaku sejak perkawinan dilangsungkan.

\footnotetext{
${ }^{2}$ K. Wantijk Saleh, 1980, Hukum Perkawinan Indonesia, Cet VI, Ghalia Indonesia, Jakarta, h.14.
} 
4. Selama perkawinan berlangsung perjanjian tersebut tidak dapat dirubah, kecuali bila dari kedua belah pihak ada persetujuan untuk merubah dan perubahan tidak merugikan pihak ketiga. ${ }^{3}$

Perjanjian kawin dilakukan seacara tertulis atas persetujuan kedua belah pihak. Hal ini menimbulkan konsekuensi hukum yang berarti para pihak telah mengikatkan diri pada perjanjian tersebut dan tidak boleh melanggar perjanjian tersebut (1313BW). Para pihak harus menaaati perjanjian ini sebagaimana diatur dalam BW. Sebagai sebuah perjanjian maka bila salah satu pihak melakukan pelanggaran (inkar janji) dapat dilakukan gugatan baik gugatan cerai atau ganti rugi.

Perjanjian kawin biasanya disusun sebelum dilangsungkannya perkawinan. Hal ini bertujuan mengatur terlebih dahulu sebelum adanya pernikahan. Sehingga hak dan kewajiban para pihak akan menjadi jelas. Pembuatan perjanjian sebelum ada perkawinan adalah agar perjanjian tersebut berlaku efektif ketika perkawinan tersebut dilangsungkan. Sebab ada kemungkinan jika perjanjian kawin dilaksanakan setelah adanya perkawinan akan menjadi sebuah hal yang aneh. Karena masih saja memikirkan harta sedangkan sudah saling terikat. Hal ini berarti ada indikasi untuk melakukan perceraian atau memang sejak awal motivasi perkawinan tersebut adalah motivasi ekonomi atau politis.

Perkawinan dikenal dengan adanya perjanjian perkawinan yang mana sering dibacakan calon suami setelah akad nikah. Yakni takli' talak. Perjanjian lainya yang sering dilakukan adalah perjanjian tentang harta Bersama. Perjanjian perkawinan adalah persetujuan yang dilakukan oleh calon memperlai berdua pada waktu atau sebelum perkawinan dilangsungkan, dan masing-masing berjanji akan mentaati apa yang ada pada persetujuan, yang disahkan oleh pencatatan nikah.

Perjanjian kawin harus disahkan petugas pencatatan perkawinan. Sebenarnya diperbolehkan untuk menyusun perjanjian secara pribadi atau hanya melibatkan pihak ketiga. Kemudian surat perjanjian tersebut diserahkan pada

\footnotetext{
${ }^{3}$ Sudarsono, 1991, Hukum Perkawinan Nasional, Rineka Cipta, Jakarta, h.7.
} 
pagawai pencatatan untuk dilakukan pengesahan. Perjanjian kawin yang dilakukan seperti itu dikatakan sah namun kekuatan hukumnya lemah.

Oleh karena itu banyak pihak yang membuat perjanjian ini dihadapan Notaris dengan menggunakan akta Notariat. Jika perjanjian dilakukan dengan notaris maka kekuatan hukum perjanjian tersebut kuat dan tidak diragukan. ${ }^{4}$

Perjanjian kawin tidak dapat dirubah secara sepihak melainkan harus ada kesepakatan kedua belah pihak untuk merubahnya. Manusia kadang berubah pikiran sehingga undang-undang perkawinan mengakomodir hal ini dalam ketentuan pasal 29 (4) undang-undang perkawinan. Perubahan perjanjian juga tidak boleh melibatkan pihak ketiga dalam perjanjian. ${ }^{5}$

Hal ini tentunya, menyebabkan penulis ingin mengetahui bagaimana kehidupan masyarakat tentang adanya pembuatan perjanjian perkawinan yang dilakukan oleh notaris yang mana sudah diatur sebelumnya menurut undangundang nomor 1 tahun 1974 serta akibat hukum yang ditimbulkan menurut KUH Perdata.

Berdasarkan penjelasan tersebut diatas, maka penulis tertarik untuk melakukan penelitian dengan judul "Analisis Perjanjian Perkawinan Dan Akibat Hukumnya Ditinjau Dari Kitab Undang-Undang Hukum Perdata”.

\section{B. Metode Penelitian}

Metode Penelitian yang digunakan dalam penulisan jurnal ini adalah pendekatan yuridis normatif. Penelitian dengan yuridis normatif adalah penelitian hukum yang dilakukan dengan cara meneliti bahan pustaka atau bahan sekunder belaka. ${ }^{6}$

\footnotetext{
${ }^{4}$ R. Soetojo Prawirohamidjojo, Pluralisme dalam Perundang-undangan Perkawinan di Indonesia, Airlangga University Press, 1998. h.57.

${ }^{5}$ Ibid, h. 60.

${ }^{6}$ Sarjono Soekanto dan Sri Mamuji, Metode Penelitian Hukum Normatif Suatu Tinjauan Singkat (Jakarta: PT Raja Grafindo Persada 2007) h.13.
} 


\section{Hasil dan Pembahasan}

\section{Pembuatan Perjanjian Perkawinan Yang Dilakukan Oleh Notaris Serta} Akibat Hukum Yang Ditimbulkan Menurut KUH Perdata.

Pengertian perjanjian dapat kita lihat dalam pasal 1313 Kitab UndangUndang Hukum Perdata. Suatu perjanjian adalah suatu perbuatan dengan mana satu orang atau lebih mengikatkan dirinya terhadap satu orang atau lebih.

Perkawinan antara seorang pria dan seorang wanita menurut Kitab Undang- Undang Hukum Perdata dalam pasal 119 mengakibatkan terjadi persatuan bulat harta kekayaan perkawinan dalam hal ini pada prinsipnya dalam hubungan suami isteri tersebut hanya terdapat satu jenis kekayaan yaitu harta persatuan. Penyimpangan terhadap prinsip persatuan harta dimungkinkan oleh ketentuan pasal 139 Kitab Undang-Undang Hukum Perdata yang isinya memberi kesempatan untuk suami dan isteri untuk membuat perjanjian kawin yang isinya mengatur tersendiri harta kekayaan asal perjanjian tersebut tidak menyalahi tata susila yang baik atau tata tertib umum. ${ }^{7}$

Untuk terpenuhinya suatu perjanjian yang sah, maka harus memenuhi syarat sahnya suatu perjanjian yang mana diatur dalam Pasal 1320 KUH Perdata yaitu:

1. Sepakat mereka yang mengikatkan dirinya;

2. Kecakapan untuk membuat suatu perikatan;

3. Suatu hal tertentu;

4. Suatu sebab yang halal.

Intinya apabila perjanjian yang di inginkan para pihak tidak memenuhi syarat-syarat kesepakatan mereka yang telah mengikatkan dirinya dan/atau tidak memenuhi kecakapan untuk membuat suatu perikatan, maka perjanjian tersebut tidak sah. Maka perjanjian tersebut dapat dibatalkan. Sedangkan, apabila tidak memenuhi syarat-syarat suatu hal tertentu maupun suatu sebab yang halal maka perjanjian tersebut batal demi hukum.

Perjanjian kawin merupakan sarana untuk melakukan proteksi terhadap harta para mempelai. Melalui perjanjian ini para pihak dapat menentukan harta

\footnotetext{
${ }^{7}$ Hilman Hadikusuma, Hukum Perkawinan Indonesia, (Bandung: bandar maju 2007) h.52.
} 
bawaan masing-masing. Apakah sejak awal ada pemisahan harta dalam perkawinan atau ada harta bersama namun diatur cara pembagiannya bila terjadi perceraian. Harta bawaan dari masing-masing suami dan isteri dan harta benda yang diperoleh masing-masing sebagai hadiah atau warisan, adalah dibawah penguasaan masing-masing sepanjang para pihak tidak menentukan lain. ${ }^{8}$ Harta bersama adalah harta yang diperoleh dalam perkawinan. Hal ini menimbulkan konflik bilamana terjadi perceraian dan salah satu pihak menuntut pembagian harta. tidak menjadi masalah bila para pihak dapat melakukan kompromi. Yang sering terjadi dalam kehidupan adalah masing-masing bersikukuh untuk mengakui harta pasangannya. Pada pasal 36 UU Perkawinan dinyatakan bahwa suami atau istri masing-masing pihak dapat bertindak atas persetujuan bersama atas harta bersama dala perkawinan. Suami dan isteri juga mempunyai hak sepenuhnya untuk melakukan perbuatan hukum mengenai harta bawaan.

Maka perjanjian kawin dapat memuat pengaturan mengenai harta bersama maupun harta bawaan. Harta bawaan dapat disatukan menjadi harta bersama. Harta bersama dalam perkawinan dapat dipisahkan melalui perjanjian kawin. Sebab suami dan istri dibebaskan untuk melakukan tindakan hukum. Perjanjian kawin yang dibuat tidak melulu hanya mengatur tentang harta dalam perkawinan saja tetapi juga mengatur hak dan kewajiban para pihak. Merunut pada Pasal 34 UU No.1 tahun 1974 yang berbunyi:

“(1) Suami wajib melindungi isterinya dan memberikan segala sesuatu keperluan hidup berumah tangga sesuai dengan kemampuannya. (2). Isteri wajib mengatur urusan rumah-tangga sebaik-baiknya. (3). Jika suami atau isteri melalaikan kewajibannya masing-masing dapat mengajukan gugutan kepada Pengadilan."

Sebuah perjanjian perkawinan baru dianggap sah apabila memenuhi syarat dan ketentuan yang telah diatur dalam undang-undang. Untuk itu perhatian

\footnotetext{
8 http://www.hukumonline.com/berita/baca/lt58180e 2811d66/plus-minus-putusan-mk-tentangperjanjian- perkawinan, dikutip tanggal 17 juni 2018, pukul: 09.34 WIB
} 
terhdap aspek ini sangat penting agar kekuatan hukum dari perjanjian perkawinan itu bisa dipertanggung jawabkan.

Perjanjian perkawinan tidak dapat dilepaskan dari perjanjian secara umum disamping secara khusus sebagaimana yang diatur dalam Undang-undang Perkawinan. Secara umum syarat sahnya perjanjian ada dua macam yaitu:

1. Mengenai subjeknya, meliputi:

a. Orang yang membuat perjanjian harus cakap atau mampu melakukan perbuatan hukum

b. Kesepakatan (consensus) yang menjadi dasar perjanjian yang harus dicapai atas dasar kebebasan menentukan kehendaknya

2. Mengenai objek, yaitu apa yang dijanjikan oleh masing-masing pihak.

Untuk membuat suatu perjanjian perkawinan harus memenuhi beberapa syarat/ ketentuan sehingga tidak cacat hukum, antara lain:

a. Atas persetujuan Bersama mengadkan perjanjian

b. Suami dan isteri cakap dalam melakukan perjanjian

c. Objek perjanjian jelas

d. Tidak bertentangan dengan Hukum, agama dan kesusilaan

e. Dinyatakan secara tertulis dan disahkan oleh $\mathrm{PPN}^{9}$

Melalui perjanjian kawin dapat diatur beberapa hal yang contoh yang dianggap substansial seperti:

1. Pengaturan mengenai kewajiban suami dan istri dalam perkawinan.

2. Semisal suami wajib menafkahi keluarganya dan istri wajib mengurus keluarganya. Suami dilarang untuk menelantarkan keluarga dengan alasan apapun.

3. Larangan penggunaan kekerasan dalam perkawinan.

4. Kekerasan dalam rumah tangga (KDRT) menjadi isu yangg cukup hangat saat ini. Suami terutama dilarang melakukan kekerasn terhadap anak ataupun istri.

5. Hak asuh anak bila terjadi perceraian. Anak sering direbutkan oleh orang tuanya karena dalam pasal Pasal 41 (a) UU Perkawinan "Baik ibu atau

${ }^{9}$ Moch. Isnaeni, Hukum Perkawinan Indonesia, h.38 
bapak tetap berkewajiban memelihara dan mendidik anak-anaknya, semata-mata berdasarkan kepentingan anak;”. Tidak diatur secara jelas menenai hak asuh anak pasca perceraian. ${ }^{10}$

Perjanjian perkawinan hanya lahir dengan akta Notaris yang mana akta menjadi syarat lahirnya perjanjian kawin, sehingga perjanjian kawin seperti penjelasan diatas wajib dibuat dengan akta notaris. Diijelaskan dalam Pasal 38 ayat (3) huruf c Undang- Undang Jabatan Notaris menegaskan bahwa isi akta merupakan kehendak para penghadap.

Meskipun isi akta merupakan kehendak dari para pihak dan akan berlaku sebagaimana undang-undang yang membuatnya, tapi tetap notaris tidak harus selalu mengabulkan kehendak atau keinginan para penghadap tersebut jika bertentangan dengan peraturan perundang-undangan, norma agama, susila, sosial dan kemasyarakatan, serta ketertiban umum.

Pasca putusan MK No.69/PUU-XIII/2015 pembuatan perjanjian perkawinan yang dibuat Notaris hanya mengganti pada bagian premisse saja. Akta notaris tentunya mempunyai kekuatan pembuktian yang sempurna, apabila semua prosedur atau tata cara dan syarat yang sudah ditentukan dalam UUJN dipenuhi, dan sebaliknya dapat dibuktikan atas gugatan ataupun putusan pengadilan maka dapat saja akta dibatalkan. Kemudian dalam perjanjian perkawinan yang mana dibuatkan sevara tertulis dan disahkan oleh Pegawai pencatatan perkawina atau notrais. Perjanjian perkawinan tersebut berlaku oleh pegawai pencatatan perkainan atau Notaris. Perjanjian perkawinan ini pun berlangsung sebagai undang- undang bagi mereka yang membuatnya, juga berlaku bagi pihak ketiga sepanjang pihak ketiga tersangkut.

Melalui perjanjian kawin dapat ditentukan siapa yang berhak atas pengasuhan anak tersebut walaupun dalam taklik talak telah diatur janji-janji kawin. Namun para pihak dapat memperjanjikan dalam perjanjian kawin yang dicatatkan dalam akta notaris. Karena memiliki kekuatan hukum.

\footnotetext{
${ }^{10}$ Hazairin, Tinjauan mengenai UU Perkawinan nomer 1 Tahun 1974, Jakarta: Tintamas, 1986, h.1. 
Menurut undang-undang Suami isteri wajib saling cinta-mencintai hormatmenghormati, setia dan memberi bantuan lahir bathin yang satu kepada yang lain. Adanya perjanjian kawin melahirkan akibat hukum karena perjanjian tersebut dikehendaki oleh para pihak. Perjanjian kawin menimbulkan beberapa akibat. Secara hukum para pihak saling terkait dengan diadakannya perjanjian kawin dan masing-masing harus melaksanakan kewajiban dan haknya. Para pihak juga harus siap dengan konsekuensi hukum yang akan timbul bila melakukan pelanggaran terhadap perjanjian kawin. Secara moril dan psikologis perjanjian kawin akan menimbulkan perasaan tidak percaya terhadap pasangan hidupnya. Ia akan dibayangi perasaan takut kalau pasangannya melakukan pelanggaran terhadap perjanjian. Kecemasan ini akan mengakibatkan ketidakbahagiaan dalam menjalani rumah tangga. ${ }^{11}$

\section{Akbiat Hukum Yang Terjadi Ketika Perjanjian Perkawinan Dibuat Menurut Kuh Perdata}

Ketika suatu perkawinan telah dianggap sah sudah pasti akan menimbulkan akibat hukum dari perkawinan yaitu timbulnya hak dan kewajiban bagi kedua belah pihak. Yang dimaksud hak di sini adalah apa- apa yang diterima oleh seseorang dari orang lain, sedangkan yang dimaksud dengan kewajiban adalah yang mesti dilakukan seseorang terhadap orang lain. Dalam hubungan suami istri dalam rumah tangga, suami mempunyai hak dan begitupula istri mempunyai hak. Dibalik itu suami juga mempunyai kewajiban-0kewajiban yang harus dipenuhi begitupun istri juga mempunyai kewajiban:

1. Suami istri harus setia dan tolong menolong (pasal 103 KUHPerdata)

2. Suami dan istri wajib memelihara dan mendidik anaknya (pasal 104 KUHPerdata)

3. Setiap suami adalah kepala dalam persatuan suami istri (pasal 105 ayat 1 KUHPerdata)

\footnotetext{
${ }^{11}$ Mulyoto, 2012, Perjanjian Tehnik, Cara Membuat, dan Hukum Perjanjian yang harus dikuasi, Cakrawala Media, Yogyakarta, h. 17
} 
4. Suami wajib memberi bantuna kepada istrinya (pasal 105 ayat 2 KUHPerdata)

5. Setiap suami harus mengurus harta kekayaan milik pribadi istrinya (pasal 105 ayat 3 KUHPerdata)

6. Setiap suami berhak mengurus harta kekayaan bersama (pasal 105 ayat 4 KUHPerdata)

7. Suami tidak diperbolehkan memindatangankan atau membebani harta kekayaan tak bergerak milik istrinya tanpa persetujuan istri (pasal 105 ayat 5 KUHPerdata)

8. Setiap istri harus tunduk dan patuh kepada suaminya (pasal 106 ayat 1 KUHPerdata)

9. Setiap istri wajib tinggal bersama suaminya (pasal 106 ayat 2)

10. Setiap suami wajib membantu istrinya di muka hakim (pasal 110 KUHPerdata)

11. Setiap istri berhak membuat surat wasiat tanpa izin suami (pasal 118 KUHPerdata)

Dalam undang-undang Perkawinan juga dijelaskan mengenai hak dan kewajiban suami istri yang tercantum dalam pasal 30 sampai dengan pasal 34 UU Perkawinan, yang intinya sebagai berikut:

1. Masing-masing pihak berhak untuk melakukan perbuatan hukum (pasal 31 ayat 2 UU Perkawinan)

2. Suami adalah kepala rumah tangga dan istri adalah ibu rumah tangga (pasal 31 ayat 3 UU Perkawinan)

3. Suami istri menentukan tempat kediaman mereka (pasal $32 \mathrm{UU}$ Perkawinan)

4. Suami istri wajib saling mencintai, hormat menghormati dan saling setia (pasal 33 UU Perkawinan)

5. Suami wajib melindungi istrinya dan memberikan segala sesuatu sesuai dengan kemampuannya (pasal 34 ayat 1 UU Perkawinan)

6. Istri wajib mengatur urusan rumah tangga dengan sebaik-baiknya (pasal 34 ayat 2 UU Perkawinan) 
7. Jika suami dan istri melalaikan kewajiban masing-masing dapat mengajukan gugatan ke Pengadilan (pasal 34 ayat 3 UU Perkawinan)

Selain dari pada hak dan kewajiban tersebut masih terdapat hak lain yang merupakan akibat dari perkawinan yaitu mengenai harta benda dalam perkawinan perkawinan. Hal tersebut tercantum dalam pasal 35 sampai dengan pasal $37 \mathrm{UU}$ Perkawinan, yang dimana intinya adalah:

1. Timbul harta bawaan dan harta bersama

2. Suami atau istri masing-masing mempunyai hak sepenuhnya terhadap harta bawaan

3. Suami atau istri harus selalu ada persetujuan sebelum melakukan perbuatan hukum terhadap harta bersama

\section{Simpulan}

Berdasarkan uraian kasus tersebut dapat disimpulkan bahwa:

Analisis Yuridis tentang pembuatan perjanjian perkawinan Intinya apabila perjanjian yang di inginkan para pihak tidak memenuhi syarat-syarat kesepakatan mereka yang telah mengikatkan dirinya dan/atau tidak memenuhi kecakapan untuk membuat suatu perikatan, maka perjanjian tersebut tidak sah. Maka perjanjian tersebut dapat dibatalkan.

Untuk terpenuhinya suatu perjanjian yang sah, maka harus memenuhi syarat sahnya suatu perjanjian yang mana diatur dalam Pasal 1320 KUH Perdata yaitu:

1) Sepakat mereka yang mengikatkan dirinya;

2) Kecakapan untuk membuat suatu perikatan;

3) Suatu hal tertentu;

4) Suatu sebab yang halal. 


\section{DAFTAR PUSTAKA}

\section{Buku/ Literatur:}

Hazairin, Tinjauan mengenai UU Perkawinan nomer 1 Tahun 1974, Jakarta: Tintamas, 1986, h.1.

K. Wantijk Saleh, 1980, Hukum Perkawinan Indonesia,Cet VI, Ghalia Indonesia, Jakarta.

Masri Singarimbun dan Sofyan Effendi, Metode Penelitian Survei, (Jakarta: LP3ES 1995).

Mulyoto, 2012, Perjanjian Tehnik, Cara Membuat, dan Hukum Perjanjian yang harus dikuasi, Cakrawala Media, Yogyakarta.

R. Soetojo Prawirohamidjojo, Pluralisme dalam Perundang-undangan Perkawinan di Indonesia, Airlangga University Press, 1998.

Sarjono Soekanto dan Sri Mamuji, Metode Penelitian Hukum Normatif Suatu Tinjauan Singkat (Jakarta: PT Raja Grafindo Persada 2007).

Sudarsono, 1991, Hukum Perkawinan Nasional, Rineka Cipta, Jakarta.

\section{Sumber Lain}

\section{Dari Internet}

http://www.hukumonline.com/berita/baca/lt58180e 2811d66/plus-minus-putusanmk-tentang-perjanjian- perkawinan, dikutip tanggal 17 juni 2018, pukul: 09.34 WIB 